\title{
LITHOLOGICAL CONDITIONS OF SOIL EROSION IN THE CHWALIMSKI POTOK CATCHMENT (THE DRAWSKIE LAKELAND) AT THE BACKGROUND OF SELECTED GEOTECHNICAL ANALYSES
}

\author{
Marcin Winowski, Mikołaj Majewski
}

\begin{abstract}
Soil erosion by water is one of the most important morphogenetic processes taking place within the lowland geoecosystems in Poland. Therefore, it is relevant to recognise its nature, course, conditions and dynamics. This article presents some lithological conditions of water soil erosion on a testing plot within the Chwalimski Potok catchment in the Drawskie Lakeland. The conducted measurements of soil particle size distribution, soil moisture and compaction, shear strength and degree, as well as infiltration rate constitute the basis of the analysis and all relevant calculations. It was shown that topsoil (slightly loamy sands) with increased humidity at the surface is most susceptible to the process of soil erosion by water. Some methods to prevent adverse degradation processes were suggested in the article.
\end{abstract}

Keywords: lithological conditions of soil erosion, soil erosion by water, geotechnics, Drawskie Lakeland, Zachodniopomorskie Voivodship

\section{Introduction}

At the time of the observed climatic changes leading to an increase in the number of extreme nature events, the issue of degradation of upper lithospheric layers requires special attention. Water erosion commonly taking place on inclined surfaces which are not covered with vegetation (depending on the intensity of the 
main morphogenetic factor, namely precipitation) may take various values. Water erosion is most often initiated by surface runoff. According to the infiltration theory of runoff developed by Horton (1945), surface runoff is the difference between the amount of water coming from precipitation and water infiltrating into the ground. It depends on the infiltration rate.

Soil erosion by water is affected by numerous factors. The USLE and RUSLE models are most commonly applied (out of the numerous mathematical models which specify potential soil erosion). According to them, soil erosion by water is affected by 6 factors: erosivity of rainfall and snowmelt, length of slope and its inclination, type of cultivation and usage of land, anti-erosion treatments and susceptibility of soils to erosion. While most of these factors depend on one variable, susceptibility of soils to erosion is more complicated. It is affected by a variety of physical properties of soil, which include: particle size distribution, permeability depending on compaction, infiltration rate and shear strength (Wischmeier, Smith 1978; Renard et al. 1997; Rejman et al. 2008).

As already mentioned, lithological soil conditions (particle size distribution, compaction and humidity) - among numerous determinants of soil erosion by water - deserve special attention. They determine the level of water infiltration into the ground. High infiltration (high values of its rate) will allow surface sediments to adopt more water, thus delaying the formation of surface runoff. In the case of low soil permeability, the main process leading to land fragmentation takes place considerably faster. Cohesive soils characterised by increased compaction allow for much better runoff than sandy sediments characterised by larger relaxation. Among sediments which are conducive to the occurrence of surface runoff it is possible to distinguish ones which are characterised by higher or lower susceptibility to the presence of water erosion. It is conditioned by immune features of soils i.e. cohesion and shear strength.

In Poland the most extensive transformation of land surfaces resulted from soil erosion is observed in the Carpathians and in the Lublin region, as well as within the boundaries of the Pomeranian Lakeland (Józefaciuk, Józefaciuk 1994; Koćmit 1998; Szpikowski 1998, 2003; Kostrzewski 2001). Lakeland areas, when compared to mountains and highlands, are characterised by reduced levels and intensity of water erosion (Reniger 1950; Józefaciuk, Józefaciuk 1994). It is determined by some natural (climatic, hypsometric and lithological) conditions (Koćmit 1998).

The occurrence and intensity of soil erosion by water within the lowland part of Poland are characterised by spatial variability. In reference to other lowland areas, the area of lakelands, characterised by considerable land height variances, has more potential energy which favours erosion processes (Kostrzewski 1993). The research studies on soil erosion by water in the lakelands have been so far based on measurements on solid testing plots (Klimczak 1993; Kosturkiewicz, 
Szafrański 1993; Szpikowski 1998, 2001, 2003, 2010; Smolska 2002, 2005, 2010; Szafrański, Stasik 2001; Majewski 2014, 2016), individual extreme events (Rataj 1977; Kostrzewski et al. 1989; Podlasiński 2007; Smolska 2008) and soil erosion in regional terms (Lankauf 1975; Uggla et al. 1998; Koćmit et al. 2006). On the basis of the obtained research results conducted in the lakelands, it is possible to qualitatively and quantitatively specify erosion processes in the current denudative world. They also allow to specify characteristics and trends of the development of erosion processes (Kostrzewski 2001).

The main objective of the present paper is to recognise the lithological conditions of soil erosion on the basis of the research studies of some selected geotechnical parameters conducted on a selected testing plot within the Chwalimski Potok catchment (the Drawskie Lakeland). The studies com, among others, determination of soilparticle size distribution, its natural humidity $\left[\mathrm{W}_{n}\right]$, compaction $\left[\mathrm{I}_{\mathrm{D}}\right]$, shear strength $\left[\mathrm{T}_{\mathrm{fu}}\right]$ and degree, as well as infiltration rate $[\mathrm{K}]$. The implementation of the adopted research problem enables to check the usefulness of geotechnical methods applied in research studies on soil erosion by water, indication of areas being susceptible to this process (within the studied area) and presentation of methods to counter the effects of degradation.

Research including geotechnical conditions of soil erosion in Western Pomerania have been so far conducted only to commercial order. The results haven't been published yet and hence there is a great need to enrich literature in this subject.

\section{Study area}

Investigations of lithological conditions of soil erosion were conducted on a testing plot selected within the Chwalimski Potok catchment (Fig. 1). According to the physiographical division of Poland, the Chwalimski Potok is located in the mezoregion of the Drawskie Lakeland, in the macroregion of West Pomerania (Kondracki 2009). According to the hydrographical divisions, the discussed area is located within the 1 st order catchment being a subsystem of the Młyński Potok catchment and then followed by the upper Parsęta catchment. The location of the area in the upper Parsęta catchment (which can be regarded to be representative for young glacial areas of the temperate climatic zone (Kostrzewski et al. 1994) determines formation of the current landscape structure, including the operation of soil erosion by water within (Kostrzewski 1998; Szpikowski 2001).

The area where the research studies were conducted is an experimental plot on which regular studies on soil erosion have been run since the early 90s (Szpikowski 1998, 2001, 2003, 2010; Majewski 2014, 2016). This area covers 4.8 hectares and is characterised by short slopes with small height variances up to 10 meters. 


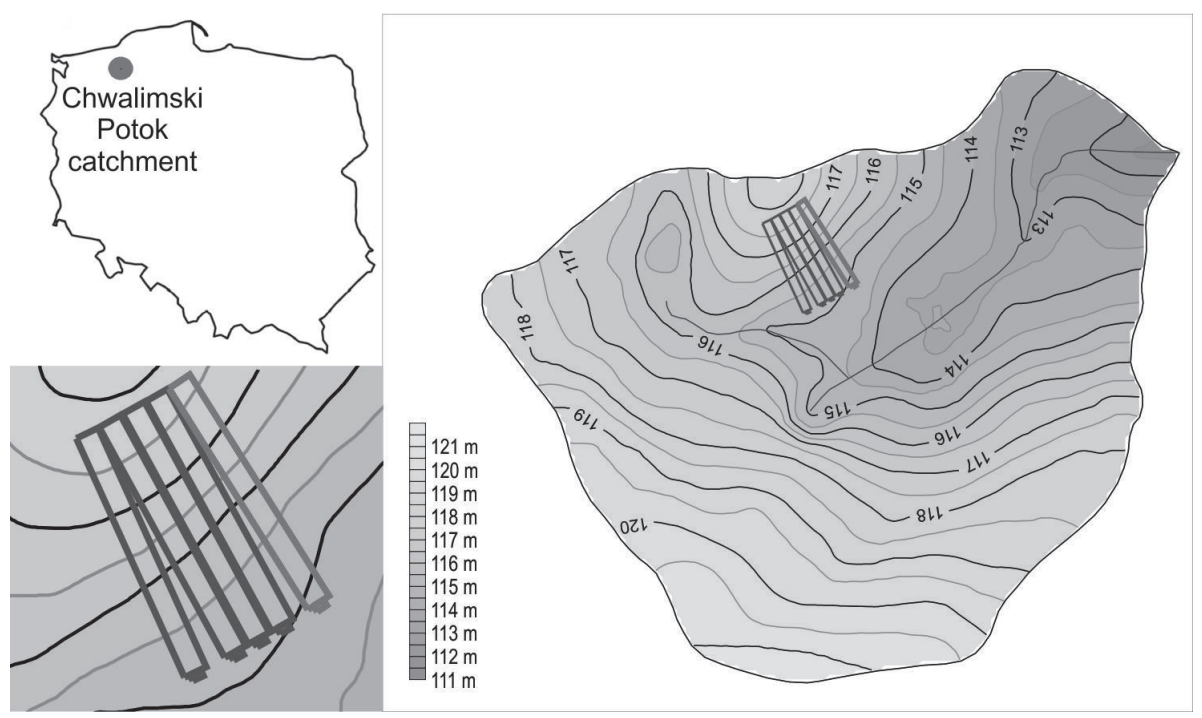

Fig. 1. Location of the research area and testing plots with the black fallow areamarked

Source: authors' own study.

According to Karczewski (1991), the Chwalimski Potok is located within an area of ground morainic uplands which are part of the highest northern upland slope of the Pomeranian region. Historically, the area was covered with agricultural crops; currently they cover about $10 \%$ of the area (Szpikowska 2012).

The slope with the testing plot for surface runoff and wash-off is covered with Gleyic Retisols (Marcinek, Komisarek 1998). The average slope inclination is about $4^{\circ}$ with its south-east exposure. The measuring system of soil erosion by water covers a plot with its length of 42 meters and width of 7 meters (Fig. 1). The plot is occupied by black fallow (Photo 1 ).

This black fallow testing plot was selected to conduct the adopted research program due to the fact that the vegetation (in particular its root systems) which grows at the remaining testing plots could distort the actual geotechnical conditions of topsoil.

\section{Materials, methods}

In order to characterise the susceptibility of soils to water erosion within the black fallow testing plot, at first the type of sediments was specified at a depth of $1 \mathrm{~m}$ by means of the macroscopic method with the application of a geomorphological 


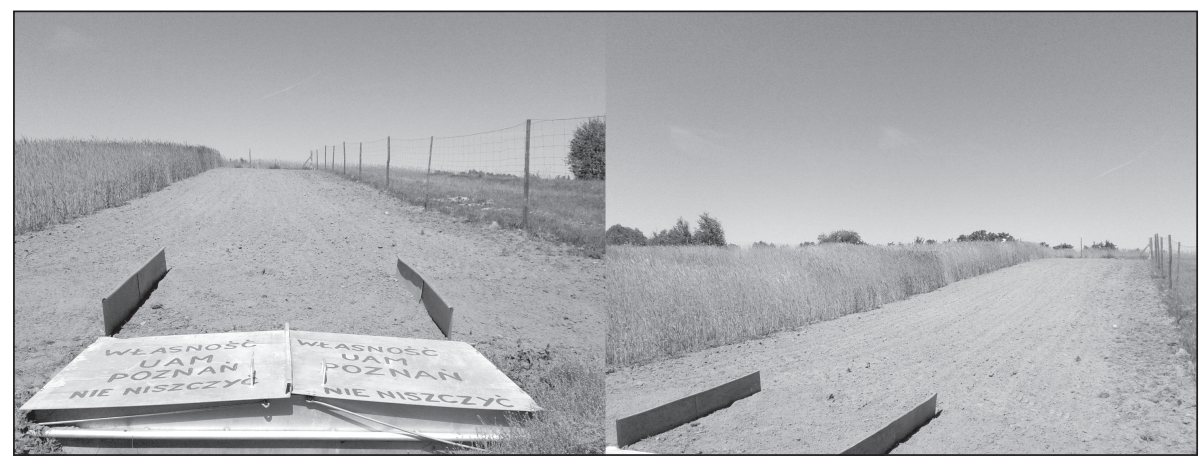

Photo 1. Testing plot covered with black fallow (photo by M. Majewski)

auger made by Eijkelkamp in line with the PN-B-04452: 2002 standard. Topsoil sediments at all the profiles were subjected to the sieving analysis (the Casagrande method) for an accurate diagnosis of particle size distribution; the classification of soils and mineral sediments by PTG (2008) was applied for this purpose. The natural humidity of all sediment samples was also determined - in laboratories through the method of weight loss under drying. To characterise the geotechnical parameters of cohesive soils, in-situ research was conducted on (1) compaction $\left[\mathrm{I}_{\mathrm{D}}\right]$ with the use of a light probe (SD-10) with a conical end and (2) on shear strength $\left[\mathrm{T}_{\mathrm{fu}}\right]$ with the use of a probe (SLVT) with a cross end in line with the PN-B-04452: 2002 standard. Compaction $\left[\mathrm{I}_{\mathrm{D}}\right.$ ] was measured by probing every $10 \mathrm{~cm}$ and shear strength - every $30 \mathrm{~cm}$ in accordance with the PN-B-04452: 2002 standard. The liquidity index $\left[\mathrm{I}_{\mathrm{L}}\right]$ for cohesive soils was determined in accordance with the Casagrande method.

In order to determine soil infiltration (its degree and rate), a double-ring infiltrometer (by Eijkelkamp) was used. Measurements were conducted at 14 standpoints, each measurement took 60 minutes. Cumulative infiltration was directly obtained from the conducted measurements and infiltration rate was calculated on the basis of the following infiltration equations by Philip (1957):

$i(t)=S t^{\frac{1}{2}}+A t$

$v(t)=\frac{1}{2} S t^{-\frac{1}{2}}+A$

where:

$i(t)$ - cumulative infiltration;

$v(t)$ - infiltration rate;

$S$-sorptivity; 
$t$ - time;

$A-$ constant.

The infiltration rate curve tends to an asymptote equal to the infiltration rate (K), which can be calculated by the following formula:

$K=\frac{A}{m}$

where $\mathrm{m}$ is a constant equal to 0.66667 (2/3) (Bátková et al. 2013).

The obtained results were used to demonstrate the spatial variability of infiltration rate in a cartographic manner. The map on the spatial distribution of the tested parameter was made using the GIS-Surfer 10 application.

The lithological mapping was conducted in one transect going centrally through the black fallow plot. Five lithological profiles (marked with W1-W8 symbols) were made under the research studies (Fig. 2). Parallel to these research studies, dynamic probing (marked with S1 to S8 symbols) was run while keeping the standard of probing distances in line with the PN-B-04452: 2002 standard.

In the research on soil infiltration it is often difficult to capture clear regularities of the spatial distribution of infiltration rate, which is conditioned by the volatility of soil compaction parameters characterised by distinct locality. Careless light stepping a given testing plot may dramatically change its measured parameters, which, in turn, considerably hinders subsequent interpretation. Taking into consideration the above difficulties, the measurements on infiltration could not be conducted at the site of the previously-made drilling and probing. They were conducted in

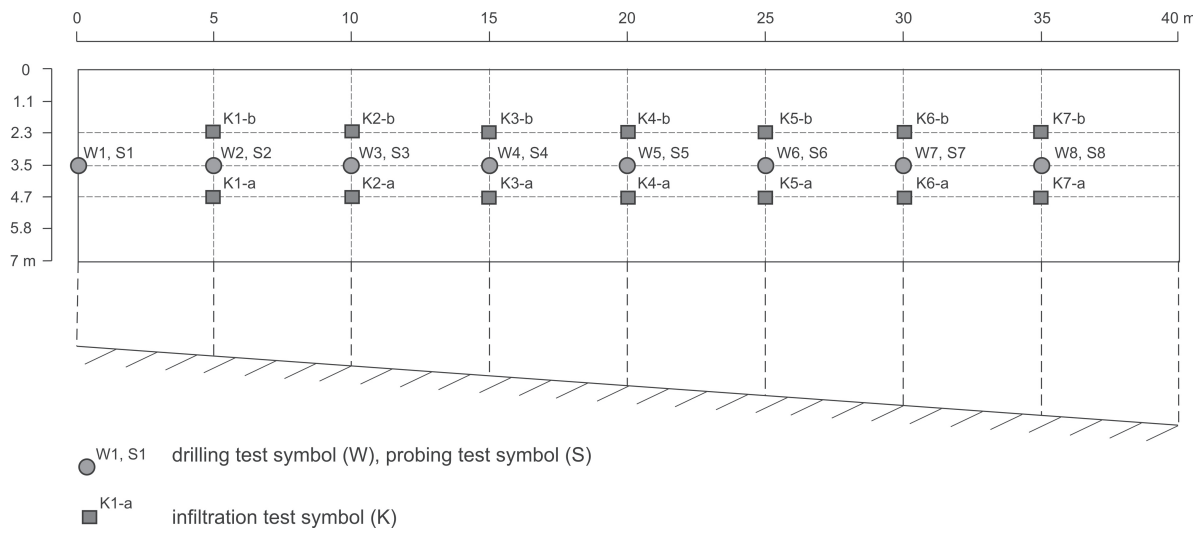

Fig. 2. Location of the measuring points within the black fallow testing plot Source: authors' own study. 
two longitudinal transects across the width of the plot equal to $2.3 \mathrm{~m}$ and $4.7 \mathrm{~m}$ and seven transverse transects spaced about $5 \mathrm{~m}$ (starting from the slope top downwards). To sum up, the measurements were conducted at 14 points (marked with K1-a up to K7-a and K1-b up to K7-b symbols) (Fig. 2).

\section{Results}

The analysed black fallow testing plot is characterised by a relatively high level of its lithological variability cross-sectioned to a depth of $1 \mathrm{~m}$. Within the entire lithological cross-section it is possible to distinguish two textural groups of sediments: sands and clays, which are then divided into four subgroups: loose sands, slightly clayey sands, sandy clays and clays (Fig. 3). The topsoil layer (plough layer) is the most homogeneous throughout the analysed cross-section. It is made of sandy sediments classified as slightly clayey sands. The thickness of these sediments ranges from $25 \mathrm{~cm}$ (within the upper parts of the slope) up to $60 \mathrm{~cm}$ (within the lower parts). The larger thickness of this series within the lower parts can be explained by being an effect of deposition derived from wash and ploughing process, thus it should be defined as ploughed diluvium layer. Within the upper parts of the slope at a depth below $25 \mathrm{~cm}$ of the P1 profile, a series of slightly clayey sands transforms into loose sands. It is difficult to clearly determine the spatial range of these sediments as no drills were made. Down the slope, from the $\mathrm{P} 2$ profile at a depth of $30 \mathrm{~cm}$, a series of slightly clayey sands is underlain with a layer of sandy clay which, in turn, at a depth of approximately $60 \mathrm{~cm}$ transforms into clay which is the bedrock. Clay constitutes the smallest part within the entire lithological cross-section. Clayey sediments are mostly represented by sandy clay which wedges out from the P4 profile towards the P5 profile (its thill), giving way to loose sands. From this profile the entire cross-section is basically dominated by sandy sediments only (Fig. 3).

To sum up, the analysed testing plot - in lithological terms - can be divided into two parts: the upper and the lower one. All over the cross-section the ceiling layer is occupied by slightly clayey sands, then within the upper part (from $2 \mathrm{~m}$ up $15 \mathrm{~m}$ within the slope) the underlying layer is made by clayey sediments. The lower part (from $15 \mathrm{~m}$ up to $35 \mathrm{~m}$ within the slope) is mainly made of loose sands.

The humidity of topsoil is characterised by little variability. The amplitude of this parameter at the examined plot is $3.3 \%$ and ranges from $14.62 \%$ up to $17.92 \%$. However, it's quite clear spatial variability can be seen as it is conditioned by the lithology of sediments underlying the ceiling layer. It can be noticed that the highest humidity occurs at places where at a small depth there are clayey sediments which constitute a kind of infiltration barrier. At such places it comes to high saturation 


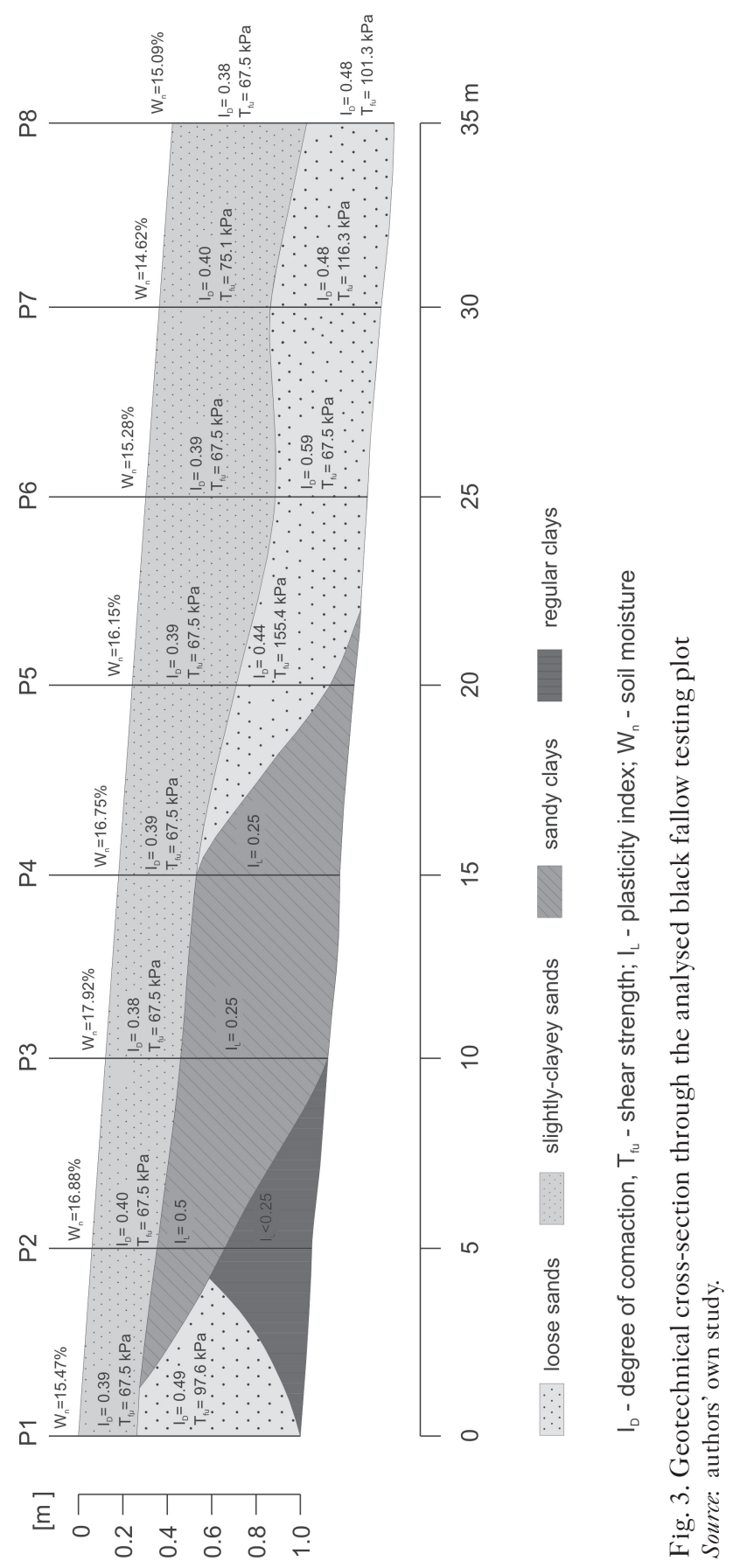


of surface sediments with water. It is noticeable in particular for the P2, P3, P4 profiles (Fig. 3). On the other hand, a lowered level of moisture is observed at places where all over the profile there are well permeable sandy sediments (the P1, P6, P7, P8 profiles) (Fig. 3).

The geotechnical parameters of the examined soils demonstrate very high homogeneity within the topsoil. The average compaction $\left[\mathrm{I}_{\mathrm{D}}\right]$ for slightly clayey sands narrowly ranges from 0.38 in the $\mathrm{P} 3$ and $\mathrm{P} 8$ profiles up to 0.40 in the $\mathrm{P} 2$ and P7 profiles (Fig. 3). The same holds true for the shear strength $\left[\mathrm{T}_{\mathrm{fu}}\right]$; here the parameters throughout are almost the same $-67.5 \mathrm{kPa}$. The $\mathrm{P} 7$ profile is the sole exception where the measured value was equal to $75.1 \mathrm{kPa}$ (Fig. 3 ). The measured parameters of both liquidity and shear strength are low and their minor spatial variability results from the application of systematic agricultural treatments. Within the analysed testing plot, disc harrowing is applied down to a depth of $15 \mathrm{~cm}$, thus its immune parameters will always be reduced. It changes along with an increase in depth of the analysed profiles where for sandy sediments we observe a slight increase in compaction (from 0.44 at the P5 profile up to 0.59 at the $\mathrm{P} 6$ profile) and a significant increase in shear strength (from $67.5 \mathrm{kPa}$ at the $\mathrm{P} 6$ profile to $155.4 \mathrm{kPa}$ at the $\mathrm{P} 5$ profile). As for clay sediments, they usually occur in their hard-plastic state $I_{L}<0.25$ (the $P 2$ profile below $60 \mathrm{~cm}$ of its depth and the P3 and P4 profiles) and plastic state $I_{L}=0.5$ (the P2 profile between $30 \mathrm{~cm}$ and $60 \mathrm{~cm}$ of its depth). The increased plasticity of clay sediments leads to a decrease in shear strength, which in turn determines increased susceptibility to degradation processes. It can be observed for the P2 profile (Fig. 3).

To sum up, the highest susceptibility to soil erosion by water is demonstrated by sediments within the topsoil, which is due to reduced compaction and shear strength. In case of sediments lying somewhat deeper the highest susceptibility to degradation processes is demonstrated by sandy sediments.

Among clayey sediments the highest susceptibility to degradation is demonstrated by sediments with increased plasticity. The degradation process will take longest in the case of clayey sediments, which is conditioned by their reduced plasticity.

Soil infiltration capacity is another relevant factor taken into account in the research on soil susceptibility to water on the analysed testing plot. Infiltration is closely linked to surface runoff. During intense precipitation, when its intensity exceeds soil infiltration capacity (infiltration rate), it increases the surface of underground waters. In the case of intersecting the area of saturation with the ground surface, water starts to flow down the slope, creating runoff (Horton 1945; Słupik 1981). Research conducted in Chwalimski Potok catchment in 2000-2014 revealed that the mean rainfall intensity on the testing plot equals $4.56 \mathrm{~mm} \cdot \mathrm{h}^{-1}$ (Majewski 2016). This value may be considered as secular pluvial conditions in this area and it does not exceed the threshold of efficient rainfall $\left(5 \mathrm{~mm} \cdot \mathrm{h}^{-1}\right)($ Rejman 
2006). However, in extreme conditions, rainfall intensity in the catchment can attain a value above $50 \mathrm{~mm} \cdot \mathrm{h}^{-1}$ (Majewski 2016).

The cumulative infiltration and infiltration rate were characterised by their spatial variability within the analysed testing plot (Fig. 4, Fig. 5, Fig. 6, Tab. 1). The highest cumulative infiltration, sorptivity and infiltration rates were recorded within the lower part of the testing plot (K5-a, K6-a). The maximum value of the examined parameters within the indicated area stood at, respectively: $6535.13 \mathrm{ml}$ $-12045.8 \mathrm{ml} ; 0.0801 \mathrm{~cm} \cdot \mathrm{s}^{-0,5}-0.1595 \mathrm{~cm} \cdot \mathrm{s}^{-0,5} ; 1.84 \cdot 10^{-3} \mathrm{~cm} \cdot \mathrm{s}^{-1}-3.09 \cdot 10^{-3} \mathrm{~cm} \cdot \mathrm{s}^{-1}$. On the other hand, the lowest values were recorded in the upper and middle part of the plot (the K1-a, K3-b, K4-b and K5-b profiles). In this case the measured values were at the following levels, respectively: $741.83 \mathrm{ml}-1377.68 \mathrm{ml} ; 0.0088$ $\mathrm{cm} \cdot \mathrm{s}^{-0,5}-0.0312 \mathrm{~cm} \cdot \mathrm{s}^{-0,5} ; 2.2 \cdot 10^{-4} \mathrm{~cm} \cdot \mathrm{s}^{-1}-1.510-4 \mathrm{~cm} \cdot \mathrm{s}^{-1}$. In general terms, for the conducted measurements taking 60 minutes, the level of cumulative infiltration ranged from $1.05 \mathrm{~cm}$ up to $17.05 \mathrm{~cm}$, which - when calculated into millilitres - ranged from approximately $740 \mathrm{ml}$ to over $12000 \mathrm{ml}$ of water used. In turn, the infiltration rate $\mathrm{K}$ ranged from $2.2 \cdot 10^{-4}$ up to $3.09 \cdot 10^{-3}$, which classifies soils at all measurement sites to the group of well-permeable soils (Pazdro 1983).

Table 1. Soil filtration parameters within the examined black fallow testing plot

\begin{tabular}{|c|c|c|c|c|}
\hline \multirow{2}{*}{$\begin{array}{c}\text { Measuring } \\
\text { point }\end{array}$} & \multicolumn{2}{|c|}{ Cumulative infiltration } & Sorptivity & Infiltration rate \\
\cline { 2 - 5 }$\left[\begin{array}{c}{[\mathrm{cm}]} \\
\text { K1-a }\end{array}\right.$ & 1.05 & 741.83 & 0.0088 & {$\left[\mathrm{~cm} \cdot \mathrm{s}^{-1}\right]$} \\
\hline K1-b & 4.65 & 3285.23 & 0.0372 & $2.2 \cdot 10^{-4}$ \\
\hline K2-a & 3.90 & 2755.35 & 0.0317 & $9.31 \cdot 10^{-4}$ \\
\hline K2-b & 3.50 & 2472.75 & 0.0283 & $7.94 \cdot 10^{-4}$ \\
\hline K3-a & 7.00 & 4945.50 & 0.0541 & $7.09 \cdot 10^{-4}$ \\
\hline K3-b & 1.95 & 1377.68 & 0.0312 & $1.35 \cdot 10^{-3}$ \\
\hline K4-a & 2.70 & 1907.55 & 0.0424 & $1.5 \cdot 10^{-4}$ \\
\hline K4-b & 1.55 & 1095.08 & 0.0138 & $1.5 \cdot 10^{-4}$ \\
\hline K5-a & 9.25 & 6535.13 & 0.0801 & $2.98 \cdot 10^{-4}$ \\
\hline K5-b & 1.10 & 777.15 & 0.0136 & $1.84 \cdot 10^{-3}$ \\
\hline K6-a & 17.05 & 12045.80 & 0.1595 & $1.51 \cdot 10^{-4}$ \\
\hline K6-b & 2.40 & 1695.60 & 0.0022 & $3.09 \cdot 10^{-3}$ \\
\hline K7-a & 4.35 & 3073.28 & 0.0324 & $4.45 \cdot 10^{-4}$ \\
\hline K7-b & 5.35 & 3779.78 & 0.4382 & $8.11 \cdot 10^{-4}$ \\
\hline
\end{tabular}

Source: authors' own study. 


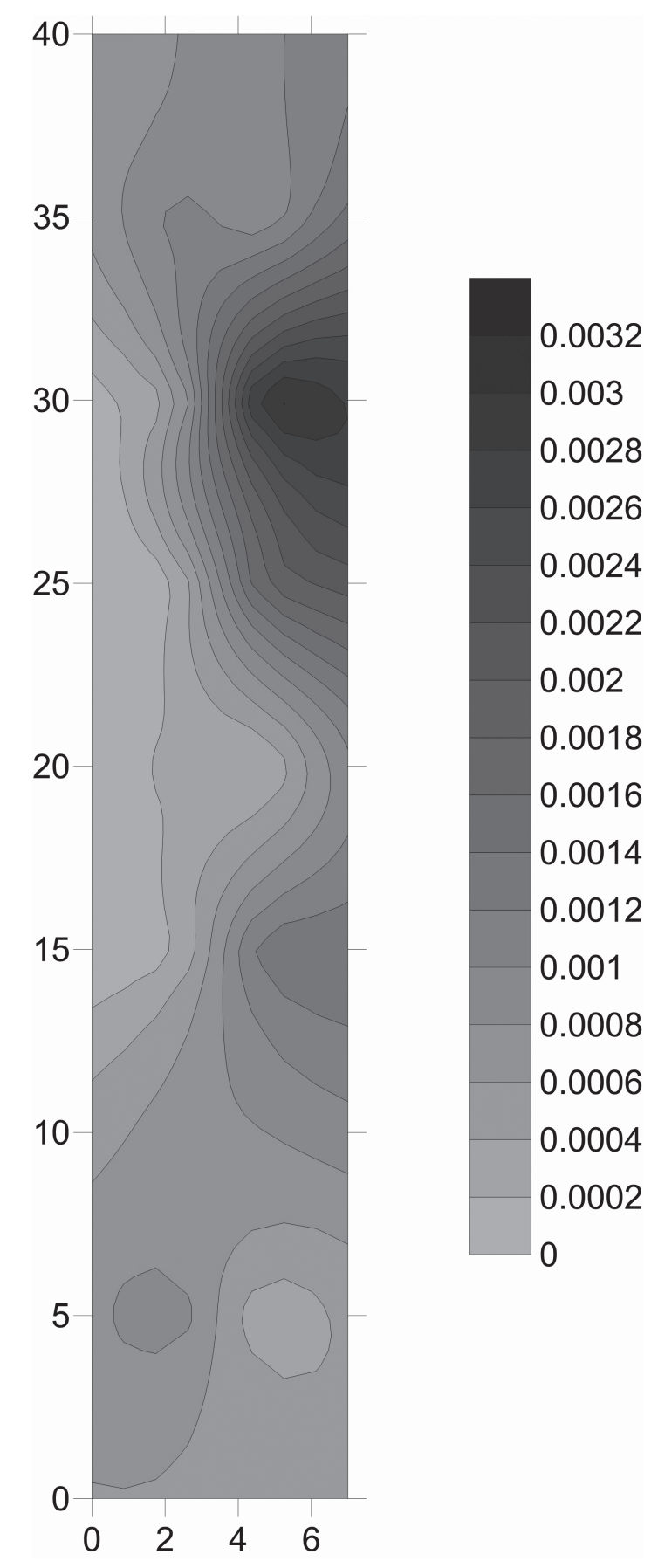

Fig. 4. Spatial variability of filtration rate $(\mathrm{K})$ within the analysed black fallow testing plot

Source: authors' own study. 


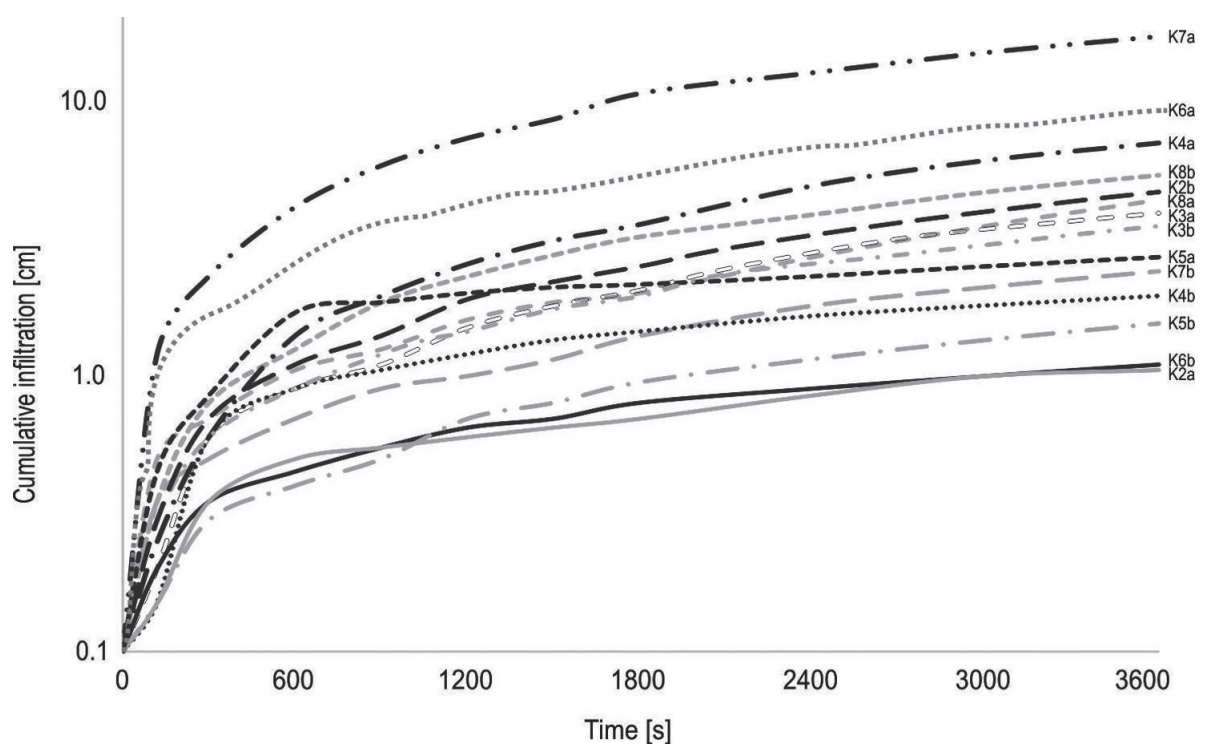

Fig. 5. Cumulative infiltration at individual measuring points Source: authors' own study.

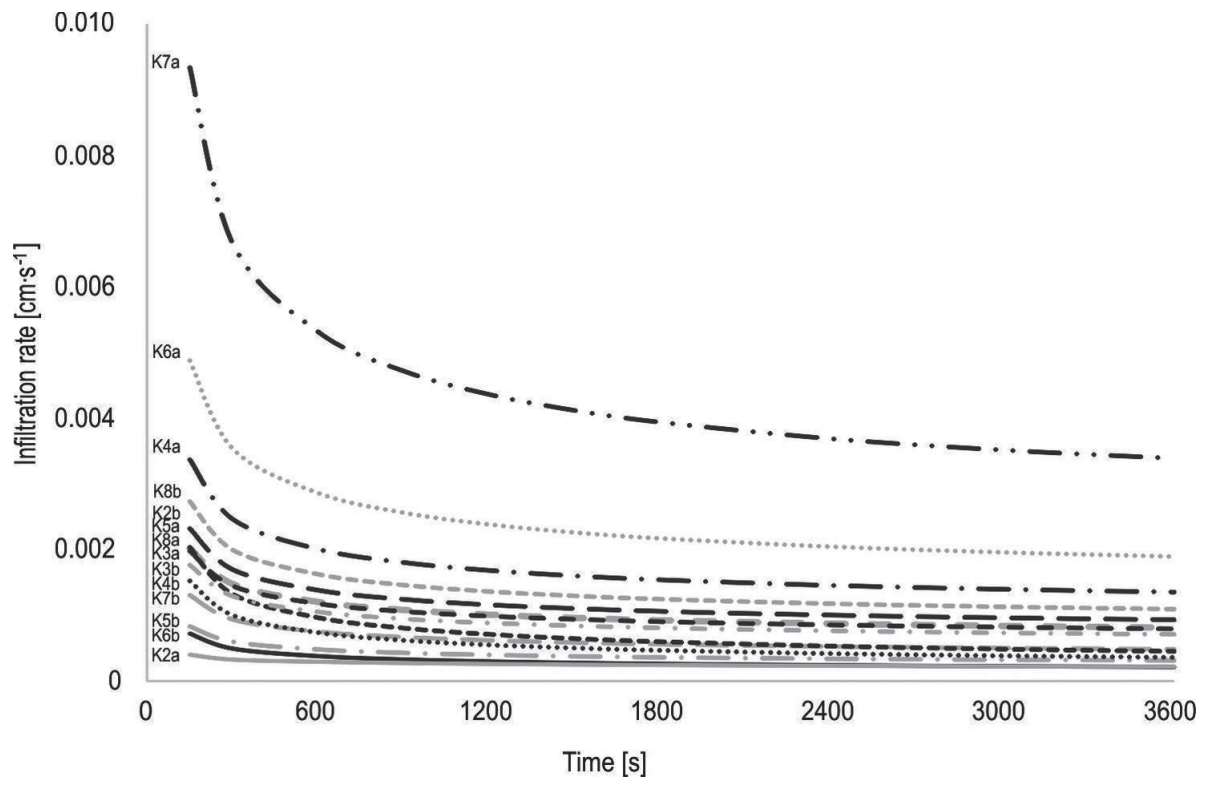

Fig. 6. Infiltration rate at individual measuring points Source: authors' own study. 
Infiltration increased steadily over time at all sites. This increase was almost uniform throughout the measurement (it was higher within the first minutes and then regularly decreased in the following minutes (Fig. 5). On the other hand, the temporal variability of infiltration rate was clearly perceptible. Within the initial minutes it decreased dramatically (this decrease ranged from $20 \%$ up to $35 \%$ within the first 5 minutes) and then from about the $10^{\text {th }}$ minute this decrease got reduced and approached the infiltration rate K (Fig. 6).

In the case of the examined testing plot, it is possible to observe some regularities in the spatial distribution of soil infiltration capability. Generalising the obtained results it should be stated that the process of infiltration takes place most quickly in the lower part of the slope; the sediments which occur there are characterised by their relatively low humidity because they are underlain with permeable layers of sandy sediments. On the other hand, the lowest values of the specified parameter are observed in the upper and middle part of the slope characterised by their highest humidity, which is conditioned by shallow retention of impermeable sediments.

In order to counteract these negative conditions, subsoiling (ploughing to a depth below the normal ploughing level and so breaking up the subsoil) and vertical drainage could turn out to be the most effective treatment (drainage is already well-known and widely used in building engineering). It consists in drilling the impermeable layer in the previously planned grid and draining excess water into its underlying permeable layer. The set of holes is then filled with well-permeable material (gravel, coarse sand). The presented treatment will surely contribute to lowering the excessive humidity of surface sediments and to increasing their infiltration capability, which, in turn, would lead to a reduction in water erosion.

\section{Discussion and conclusion}

The conducted research on the lithological conditions of soil erosion by water in the Chwalimski Potok catchment (a black fallow testing plot) demonstrated that surface sediments (slightly loamy sands) show their relatively high susceptibility to degradation due to their significant relaxation and reduced shear strength, which is conditioned by conducting regular agricultural treatments.

The research conducted on this testing plot in 2012-2014 showed, that measured soil erodibility (called K-factor in the USLE) equalled $0.0216 \mathrm{Mg} \cdot \mathrm{h} \cdot \mathrm{MJ}^{-1} \cdot \mathrm{mm}^{-1}$, and was slightly higher than the value calculated using the USLE formula. This may be considered as a moderate value, because soil erodibility in other lowland area (Suwalskie Lakeland) was five times lower (Smolska 2010), but in the Carpathian Foothills it was significantly higher (Święchowicz 2012). 
In the case of water erosion, soil infiltration capability is considered to be a very important factor. The more absorbent the soil is (the more quickly it absorbs water), the later its surface runoff, along with its related wash-off and linear erosion, starts (they start much later on little permeable soils). Soil infiltration capability is also impacted by soil moisture. Sediments over-saturated with water lose their infiltration capability, which leads to increased runoff. Taking into consideration the above conditions it should be stated that within the examined testing plot the upper and middle parts of the slopes are most susceptible to soil erosion by water. This is conditioned by the presence of impermeable sediments in the shallow ground being the cause of increased humidity at the surface. It does not, however, lead to any prolonged time of infiltration. In the case of precipitation with higher intensity, this ground is not able to adopt more water, which results in the start of surface runoff and related water erosion. On the other hand, erosion will be initiated in the lower parts of the slope last, which is due to higher infiltration capability of surface sediments which are present there and which are underlain with well-permeable sandy sediments (which do not form any infiltration barriers).

According to the soil erosion susceptibility classification, proposed by the Józefaciuks (1975), soils within the testing plot are in the third group of soils with average susceptibility to soil erosion by water.

The phenomenon of water erosion is undoubtedly an undesirable process within areas utilised for agricultural purposes. This process leads to the degradation of developed soil profiles and reduces the yield, which leads to extensive financial losses for agricultural producers. Prevention of water erosion has caused numerous difficulties for a long time. This problem is mainly due to the very complex nature of degradation processes. The research results presented in this paper emphasise the issue which has not been adequately covered in the literature. Namely, the initiation and levels of soil erosion by water - to a large extent - depend not only on the type of sediments which are subjected to this process but mainly on the type of sediments which underlie them. The conducted research studies clearly show that areas which are underlain with impermeable sediments are the ones which are the most susceptible to water erosion. To counteract water erosion under such circumstances, it is necessary to reduce the level of moisture within the surface soil layer. This is possible, among others, through the application of vertical drainage.

\section{Acknowledgements}

The study in 2014 was financed by the NCN research project No. N N304 274340 entitled:

"The current state and functioning of the natural environment within the selected areas of West Pomerania region under climatic changes and increased anthropopressure”. 


\section{References}

Bátková K., Matula S., Miháliková M., 2013, Multimediálni učebnice hydropedologických terénnich měrení. 2. doplněné vydáni [on-line]. Česká verze. Česká zemědělská univerzita v Praze. Praha. Nestránkováno, http://hydropedologie.agrobiologie.cz (14.07.2015).

Horton R., 1945, Erosional development of streams and their drainage basins: Hydrophysical approach to quantitative morphology, Bulletin of the Geological Society of America, 56, 275-370.

Józefaciuk Cz., Józefaciuk A., 1975, Komentarะ do instrukcji w sprawie inwentaryæacji gruntów sagrośonych erozjq, Wydawnictwo IUNG, Puławy.

Józefaciuk A., Józefaciuk Cz., 1994, Próba erozyjnej regionalizacji obszarów Polski dla celów melioracji przeciwerozyjnych, Roczniki Akademii Rolniczej w Poznaniu, 266, 273-280.

Karczewski A., 1991, Rozwój $i$ zasięg fazy pomorskiej w obrębie lobu Parsęty podczas zlodowacenia vistuliańskiego, [in:] A. Kostrzewski (ed.), Geneza, litologia i stratygrafia utworów czwartorzędowych, Geografia, 50, Wydawnictwo Naukowe UAM, 59-66.

Klimczak R., 1993, Sptukiwanie na obszarach o wró:nicowanym ü̇ytkowaniu-przebieg i rola we wspótczesnym środowisku morfogenetycznym (zlewnia Mtyńskiego Potoku, Pomorze Zachodnie), [in:] A. Kostrzewski (ed.), Geoekosystem obsæarów nizinnych, Wydawnictwo PAN, 61-78.

Koćmit A., 1998, Erozja wodna w obszarach mtodoglacjalnych Pomorza i możliwości jej ograniczenia, Bibliotheca Fragmenta Agronomica, 4B/98, 83-99.

Koćmit A., Podlasiński M., Roy M., Tomaszewicz T., Chudecka J., 2006, Water erosion in the catchment basin of the Jeleni Brook, Journal of Water and Land Development, 10, 121-131.

Kondracki J., 2009, Geografia regionalna Polski, Wydawnictwo Naukowe PWN, Warszawa.

Kostrzewski A., 1993, Geoekosystem obszarów nizinnych. Koncepcja metodologiczna, [in:] A. Kostrzewski (ed.), Geoekosystem obszarów nizinnych, Ossolineum, Wydawnictwo PAN „Człowiek i Środowisko”, 6, 11-17.

Kostrzewski A., 1998, Struktura krajobrazowa dorwecza Parsęty w oparciu o dotychczasowe podziały fizyczno-geograficzne, [in:] A. Kostrzewski (ed.), Funkcjonowanie geoekosystemów

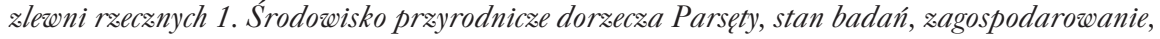
ochrona, 131-141.

Kostrzewski A., 2001, Stan badań erozji gleb na Pomorzu Zachodnim, Folia Universitais Agriculturae Stetinensis, 217, Agricultura 87, 117-124.

Kostrzewski A., Klimczak R., Stach A., Zwoliński Z., 1989, Morphologic effects of heavy rainfall (24 may, 1983) over relief features of the scrapland in the middle Parseta valley, West Pomerania, Poland, Quaestiones Geographicae, Special Issue, 2, 101-110.

Kostrzewski A., Mazurek M., Zwoliński Z., 1994, Dynamika transportu fluwialnego górnej Parsęty jako odbicie funkcjonowania systemu :lewni, Bogucki Wydawnictwo Naukowe, Poznań.

Kosturkiewicz A., Szafrański Cz., 1993, Sptywy powierzchniowe i podpowierzchniowe z bogato ræę́bionych terenów, [in:] A. Kostrzewski (ed.), Geoekosystem obszarów nizinnych, Ossolineum, Polska Akademia Nauk. Komitet Naukowy przy Prezydium PAN Człowiek i Środowisko, $6,123-130$. 
Lankauf K.R., 1975, Wspótczesne procesy sptukiwania na zboczach dolin w okolicach Torunia, Czasopismo Geograficzne, 46 (2), 191-206.

Majewski M., 2014, Wykorzystanie eksperymentu terenowego w badaniach erowji wodnej gleb w zlewni Chwalimskiego Potoku (Pojezierze Drawskie, górna Parsęta), Prace Geograficzne, 138, 57-66.

Majewski M., 2016, Sekularne i ekstremalne procesy erozji wodnej gleb na Pojezierzu Drawskim, maszynopis pracy doktorskiej, Biblioteka Główna UAM.

Marcinek J., Komisarek J., 1998, Badania gleboznawcze nad zróżicowaniem pokrywy glebowej wobrębie powier chni testowej ZMŚP w Storkowie, [in:] A. Kostrzewski (ed.), Funkcjonowanie i tendencje rozwoju geoekosystemów Polski, Biblioteka Monitoringu Środowiska, 31-50.

Pazdro Z., 1983, Hydrogeologia ogólna, Wydawnictwa Geologiczne, Warszawa.

Philip J.R., 1957, The theory of infiltration: 4. Sorptivity and algebraic infiltration equations, Soil Science, 84, 257-264.

Podlasiński M., 2007, Erozja wodna na polu ornym po intensywnym opadzie w 2007 roku w Daleszewie na Pomorzu Zachodnim, Przegląd Naukowy Inżynieria i Kształtowanie Środowiska, 2 (40), 43-49.

Rataj R., 1977, Skutki ulewy na wysoczyænie morenowej pojezierza Chetmińskiego, Czasopismo Geograficzne, 48 (1), 49-55.

Rejman J., 2006, Wpływ erosji wodnej i uprawowej na præeksঞtatcanie stoków lessowych, Acta Agrophysica, 136 (3).

Rejman J., Brodowski R., Iglik I., 2008, Annual variations of soil erodibility of silt loam developed from loess based on 10-years runoff plot studies, Annals of Warsaw University of Life Sciences - SGGW Land Reclamation, 39, 77-83.

Renard K.G., Foster G.R., Weesies G.A., McCool D.K., Yoder D.C., 1997, Predicting Soil Erosion by Water: A Guide to Conservation Planning With the Revised Universal Soil Loss Equation (RUSLE), U.S. Department of Agriculture, Agriculture Handbook, 703.

Reniger A., 1950, Próba oceny nasilenia $i$ sasięów potencjalnej erozji gleb w Polsce, Roczniki Nauk Rolniczych, 54.

Słupik J., 1981, Rola stoku w ksжtattowaniu odpływu w Karpatach fliswowych, Prace Geograficzne IGiPZ PAN, 142.

Smolska E., 2002, The intensity of soil erosion in agricultural areas in North-Eastern Poland, Landform Analysis, 3, 25-33.

Smolska E., 2005, Znaczenie sptukiwania w modelowaniu stoków młodoglacjalnych ( na przykładzie Pojezier:a Suwalskiego), WGSR UW, Warszawa.

Smolska E., 2008, Rola opadów ekstremalnych w denudacji stoków młodoglacjalnych na przykładzie Pojezierza Suwalskiego, Landform Analysis, 8, 69-72.

Smolska E., 2010, Sptyw wody i erozja gleby na piaszczystym stoku w obszarze mtodoglacjalnym (Pojezierze Suwalskie, Polska NE) - pomiary poletkowe, [in:] E. Smolska, J. Rodzik (eds.), Procesy erozyjne na stokach użytkowanych rolniczo (metody badań, dynamika i skutki), Prace i Studia Geograficzne UW, 45, 197-214. 
Szafrański Cz., Stasik R., 2001, Występowanie erowji wodnej gleb na Pojezierzu Gnieঞnieńskim w latach mokrych, Folia Universitatis Agriculturae Stetinensis, 87, 217-220.

Szpikowska G., 2012, Zmiany stężen jonów siarczanowych w wodach powierzchniowych slewni górnej Parsęty w wieloleciu hydrologicznym 1994-2011, [in:] A. Kostrzewski, J. Szpikowski (eds.), Funkcjonowanie geoekosystemów w ró:̇nych serach krajobrazowych Polski, Biblioteka Monitoringu Środowiska, 39, Storkowo, 71-82.

Szpikowski J., 1998, Wielkość $i$ mechanizm erozji wodnej gleb na stokach użytkowanych rolniczo w zlewni mtodo glacjalnej (górna Pars̨̨ta, Chwalimski Potok), Bibliotheca Fragmenta Agronomica, 4B/98, 113-124.

Szpikowski J., 2001, Uwarunkowania mechanizmu procesu rozbryzgu w mtodoglacjalnej zlewni Chwalimskiego Potoku (górna Parsęta, Pojezierze Drawskie), [in:] A. Karczewski, Z. Zwoliński (eds.), Funkcjonowanie geoekosystemów w sró:nicowanych warunkach morfoklimatycznych. Monitoring, ochrona, edukacja, Bogucki Wydawnictwo Naukowe, 511-524.

Szpikowski J., 2003, Contemporary processes of soil erosion and the transformation of the morphology of slopes in agricultural use in the postglacial catchment of the Chwalimski Potok (Upper Parsęta, Drawskie Lakeland), Quaestiones Geographicae, 22, 79-90.

Szpikowski J., 2010, Uwarunkowania $i$ wielkość rozbryzgu gleby na podstawie pomiarów na powierzchniach testowych w zlewni Chwalimskiego Potoku (Pomorze Zachodnie), Prace i Studia Geograficzne, 45, 181-195.

Święchowicz J., 2012, Wartości progowe parametrów opadów deszczu inicjujących procesy erozyjne w zlewniach usytkowanych rolniczo, Instytut Geografii i Gospodarki Przestrzennej UJ, Kraków.

Uggla H., Solarski H., Rytelewski J., Mirowski Z., Nożyński A., Grabarczyk S., 1998, Problematyka erozji wodnej gleb pótnocno-wschodniej Polski, Bibliotheca Fragmenta Agronomica, 4B/98, 179-197.

Wischmeier W.H., Smith D.D., 1978, Predicting rainfall erosion losses - a guide to conservation planning, Agricultural Handbook, 537, U.S. Department of Agriculture, Washington D.C., $1-58$.

Marcin Winowski

Adam Mickiewicz University in Poznań

Institute of Geoecology and Geoinformation

10 Bogumita Krygowskiego Str., 61-680 Poznań, Poland

e-mail:marwin@amu.edu.pl

Mikotaj Majewski

Adam Mickiewicz University in Poznań

Institute of Geoecology and Geoinformation

10 Bogumita Krygowskiego Str., 61-680 Poznań, Poland

e-mail:majewski@amu.edu.pl 
